\title{
Molecular analysis of the PROP1 and HESX1 genes in patients with septo-optic dysplasia and/ or pituitary hormone deficiency
}

\author{
Análise molecular dos genes PROP1 e HESX1 em pacientes com \\ displasia septo-ótica e/ou deficiência hormonal hipofisária
}

Juliana B. Cruz', Vania S. Nunes', Sueli A. Clara', Denise Perone', Peter Kopp², Célia R. Nogueira'

\begin{abstract}
${ }^{1}$ Universidade Estadual Paulista (Unesp), Faculdade de Medicina, Departamento de Clínica Médica, Disciplina de Endocrinologia e Metabologia, Botucatu, São Paulo, SP, Brazil 2 Divisão de Endocrinologia Metabologia e Medicina Molecular, Northwestern University, Chicago, Illinois, United States
\end{abstract}

\begin{abstract}
Objective: The present study aimed at evaluating the PROP1 and HESX1 genes in a group of patients with septo-optic dysplasia (SOD) and pituitary hormone deficiency (combined - CPHD; isolated GH deficiency - GHD). Eleven patients with a clinical and biochemical presentation consistent with CPHD, GHD or SOD were evaluated. Subjects and methods: In all patients, the HESX1 gene was analyzed by direct sequence analysis and in cases of CPHD the PROP1 gene was also sequenced. Results: A polymorphism (1772 A > G; N125S) was identified in a patient with SOD. We found three patients carrying the allelic variants $27 \mathrm{~T}>\mathrm{C}$; A9A and $59 \mathrm{~A}>\mathrm{G}$; N20S in exon 1 of the PROP1 gene. Mutations in the PROP1 and HESX1 genes were not identified in these patients with sporadic GHD, CPHD and SOD. Conclusion: Genetic alterations in one or several other genes, or non-genetic mechanisms, must be implicated in the pathogenic process. Ara Bras Endocrinol Metab. 2010;54(5):482-7

\section{Keywords}

DNA mutational analysis; septo-optic dysplasia; pituitary hormonal deficiency
\end{abstract}

\section{RESUMO}

Objetivo: O presente estudo teve como objetivo avaliar os genes PROP1 e HESX1 em um grupo de pacientes com displasia septo-óptica (DSO) e deficiência hormonal hipofisária (combinada - DHHC; ou deficiência isolada de GH - DGH). Onze pacientes com apresentação clínica e bioquímica consistente com DHHC, DGH ou DSO foram avaliados. Subjects and methods: Em todos os pacientes, o gene HESX1 foi analisado pelo sequenciamento direto e, nos casos de DHHC, o gene PROP1 foi também sequenciado. Resultados: Um polimorfismo no gene HESX1 (1772 A > G; $\mathrm{N} 125 \mathrm{~S})$ foi identificado em um paciente com DSO. Foram encontrados três pacientes portadores da variação alélica 27T > C; A9A e 59 A > G; N20S no éxon 1 do gene PROP1. Mutações no gene PROP1 e HESX1 não foram identificadas nesses pacientes com DGH, DHHC e DSO esporádicos. Conclusão: Alterações genéticas em um ou diversos outros genes ou mecanismos não genéticos devem estar implicados nesse processo patogênico. Arq Bras Endocrinol Metab. 2010;54(5):482-7

Descritores

Análise mutacional do DNA; displasia septo-óptica; deficiência hormonal hipofisária

\section{INTRODUCTION}

$\mathrm{T}$ he pituitary gland is composed of the adenohypophysis, which is comprised of an anterior and intermediate lobe, and the neurohypophysis, which consists of projections of hypothalamic magnocellular neurons (1). During development, the oral ectoderm invaginates to form the primordial rudimentary pituitary, also known as Rathke's pouch, which proliferates toward the third ventricle, where it merges with the posterior lobe (2). The posterior lobe is neural in origin, deriving from an evagination of the ventral hypothalamus and of the third ventricle (3). 
At birth, the anterior pituitary is composed of five cell types that are defined by the hormones that they secrete: corticotrophs (ACTH), thyrotrophs (TSH), somatotrophs $(\mathrm{GH})$, gonadotrophs (FSH and $\mathrm{LH})$ and lactotrophs (PRL). A series of transcription factors such as Pitl (pituitary specific transcription factor 1), PROPI (prophet of Pit1), HESXI (Homeobox embryonic stem cell), LHX3 (Lim homeobox gene 3), LHX4 (Lim homeobox gene 4), Pitxl/2 (Paired-like homeodomain transcription factor 1/2), and TPIT (T Box transcription factor), act in a temporally regulated manner to permit the progressive differentiation of these cell types (4).

Mutations in the genes encoding these factors are responsible for structural defects of the pituitary gland and hormonal deficiencies. Depending on the mutated transcription factor, these defects can be isolated, such as for example growth hormone deficiency (GHD), or they result in various forms of combined pituitary hormone deficiencies (CPHD) (5-7). The present study aimed at evaluating the PROPI and HESXI genes in a group of patients with septo-optic dysplasia (SOD), CPHD and isolated GHD.

\section{SUBJECTS AND METHODS}

Informed consent, patient assent, and approval of the hospital's Ethics Committee were obtained before initiating the study.

\section{Patients}

Eleven patients with a clinical and biochemical presentation consistent with CPHD, GHD or SOD were evaluated.

\section{Clinical evaluation}

The clinical data of patients were extracted from medical charts and included phenotypic characteristics, history of consanguinity, family history, auxological parameters and hormonal evaluation.

The criteria for inclusion were:

Growth hormone deficiency: Patients with a height less than two standard deviations (SD) below the mean, and two independent stimulation tests confirming growth hormone deficiency. The diagnostic criterion of GH deficiency was a peak GH level after stimulation < $7.0 \mathrm{ng} / \mathrm{mL}$ in the radioimmunoassay. In children with subnormal values of IGF-1 and IGFBP-3 associated with low growth velocity and deficiency of other pi- tuitary hormones, the stimulation tests were not performed. Deficiency of two or more pituitary hormones was established by formal biochemical evaluation of all endocrine axes.

Septo-optic dysplasia was diagnosed based on two or more of the following findings: 1) hypoplasia of the optic nerve, 2) midline abnormalities (including agenesis of the corpus callosum and absence of the septum pellucidum, 3) pituitary hypoplasia with hormonal deficiencies.

We studied three patients with SOD, three patients with GHD and five patients with CPHD.

\section{Hormone measurements}

To assess the function of the anterior pituitary the following hormones and binding proteins were determined: TSH, free T4, PRL, LH, FSH, GH, IGF-1, IGFBP3, Cortisol and Testosterone.

Measurement of TSH, free T4, PRL, LH, FSH, Cortisol - Chemiluminescence assay using Immulite 2000 Kits (DPC, Los Angeles, CA).

Measurement of IGF-I: Immunoradiometric assay after ethanol extraction utilizing a specific monoclonal antibody kit (Diagnostic Systems Laboratories Inc. (DSL), Webster, TX, USA).

Measurement of IGFBP3 - Immunoradiometric assay kit (DSL, Webster, TX, USA).

Measurement of GH and free testosterone - Radioimmunoassay (RIA). A value of less than $7 \mathrm{ng} / \mathrm{mL}$ was considered as insufficient in the $\mathrm{GH}$ stimulation test.

Clonidine test: (oral administration of $100 \mathrm{ug} / \mathrm{m}^{2}$ of body surface) with blood drawn for GH dosing at baseline, and at 30, 60, 90 and 120 minutes after administration of clonidine.

Insulin tolerance test: hypoglycemia was induced by i.v. administration of $0.1 \mathrm{U} / \mathrm{kg}$ of insulin. $200 \mu \mathrm{g}$ of TRH and $100 \mu \mathrm{g}$ of $\mathrm{GnRH}$ were administered at baseline for testing of the gonadal and thyroid axes. Peripheral blood was drawn for determining glucose, GH, cortisol, TSH, PRL, LH and FSH at the following points in time - $15,0,15,30,45,60,90$ and 120 minutes after administration of insulin.

\section{Radiological evaluation}

The brain and specifically the hypothalamic-pituitary region were imaged by magnetic resonance to obtain coronary and sagittal cuts at Tl with TR 350 and TE = 20 using a Tesla 0.5 magnet (Sigma GE, Milwaukee, Wisconsin, USA). 


\section{Molecular analysis}

After obtaining informed consent from all the patients and their relatives, blood was collected for genetic testing. Analysis of the HESXI gene was performed using genomic DNA isolated from peripheral blood leukocytes. Exons 1, 2, 3 and 4 were amplified by PCR with the following primers:

1F: 5'AGCTGTTGCTCTGTGCAGACCACGAGA3';

1R: 5'ACAAAGAATTGAAACAATTAAGCTGTGGCA3';

2F: 5'TTGACCATCTAAGACAGGGC3';

2R: 5'AAGTGAGTGGGCTTTTGCTC 3';

3F: 5'GAGCAAAAGCCCACTCACTT3';

4R: 5'CCACTGATTCTTCATGCTCT3'.

Amplification was performed with $100 \mathrm{ng}$ of genomic DNA in a $25 \mu \mathrm{L}$ reaction containing $20 \mathrm{pM}$ of each primer, $10 \mathrm{X}$ buffer $(50 \mathrm{mM} \mathrm{KCl}, 20 \mathrm{mM}$ Tris- $\mathrm{HCl}, \mathrm{pH}$ 8.4), $1.0 \mathrm{mM} \mathrm{MgCl}_{2}, 0.2 \mathrm{mM}$ of each dNTP, and $1.25 \mathrm{U}$ Taq DNA Polymerase (Gibco-BRL). The following PCR conditions were used: initial denaturation for 5 minutes at $94^{\circ} \mathrm{C}, 30$ cycles with $30 \mathrm{~s}$ at $94^{\circ} \mathrm{C}, 30 \mathrm{~s}$ at $55^{\circ} \mathrm{C}, 30 \mathrm{~s}$ at $72^{\circ} \mathrm{C}$ and a terminal extension at $72^{\circ} \mathrm{C}$ for 10 minutes.

Analysis of the PROPI gene was performed using genomic DNA isolated from peripheral blood leukocytes. Exons 1, 2 and 3 were amplified by PCR with the following primers:

IF: 5'ACCTACACACACATTCAGAGACAG3';

1R: 5'TGGAGCCTATGCTTTCAGC3';

2R: 5'AAAGACTGGAGCAGCACAGGACGCA3';
2R: 5' CTCAATGCAGTTGCTCCGATG3';

3F: 5'GCCTTGTGGAAGAGCTTTACTCC3';

3R: 5' ATTTCTAATCGGTGAGCTGACCC3'.

Amplification was performed with $100 \mathrm{ng}$ of genomic DNA in a $25 \mu \mathrm{L}$ reaction containing $20 \mathrm{pM}$ of each primer, $10 \mathrm{X}$ buffer $(50 \mathrm{mM} \mathrm{KCl}, 20 \mathrm{mM}$ Tris- $\mathrm{HCl}$, $\mathrm{pH} 8.4), 1.0 \mathrm{mM} \mathrm{MgCl}, 0.2 \mathrm{mM}$ of each dNTP, and 1.25 U Taq DNA Polymerase (Invitrogen). The following PCR conditions were used: initial denaturation for 3 minutes at $95^{\circ} \mathrm{C}, 30$ cycles of $30 \mathrm{~s}$ at $95^{\circ} \mathrm{C}, 30 \mathrm{~s}$ at $60^{\circ} \mathrm{C}, 2$ minutes at $72^{\circ} \mathrm{C}$ and a terminal extension at $72^{\circ} \mathrm{C}$ for 5 minutes.

PCR products were analyzed on $1 \%$ agarose gels, stained with ethidium bromide and visualized with UV light. After PCR amplification, both strands were sequenced using a Genetic Analyzer 3100 Sequencer (Applied Biosystem, Foster City, CA, USA). Sequencing was performed in the Molecular Biology Laboratory, Department of Clinical Medicine, Botucatu School of Medicine - Unesp.

\section{RESULTS}

The 11 patients were divided into the following groups according to the clinical presentation (Table 1 ):

1. Septo-optic dysplasia (patients $1,2,3$ ).

2. Isolated GH deficiency (patients 6, 7, 8).

3. Combined pituitary hormone deficiency (patients $4,5,9,10,11)$.

Table 1. Clinical data, Laboratory Measurements and Radiological Evaluation of Patients

\begin{tabular}{|c|c|c|c|c|c|c|c|c|c|c|c|}
\hline Patient & Gender & Age & $\begin{array}{l}\text { Z score } \\
\text { (height) }\end{array}$ & $\begin{array}{c}\mathrm{fT}_{4}(\mathrm{ng} / \mathrm{dL}) \\
(0.8-1.9)\end{array}$ & $\begin{array}{c}\text { TSH uU/ } \\
\text { mL } \\
(0.4-4)\end{array}$ & $\begin{array}{l}\text { FSH/LH } \\
\mathrm{mUi} / \mathrm{mL}\end{array}$ & $\begin{array}{l}\text { Cortisol } \\
\text { ug/dL }\end{array}$ & $\begin{array}{l}\text { ftesto } \\
\mathrm{pg} / \mathrm{mL}\end{array}$ & $\begin{array}{l}\text { IGF1/ } \\
\text { IGFB P3 } \\
\text { ng/mL }\end{array}$ & $\begin{array}{c}\text { GH - ITT } \\
\text { ng/mL }\end{array}$ & MRI \\
\hline 1 & $M$ & 3 y 3 m & -0.4 & 0.77 & 6.05 & $0.52 / 0.17$ & 3.52 & 15.07 & $27 / 1610$ & $\#$ & $\begin{array}{c}\text { APH/EN/ } \\
\text { ONH }\end{array}$ \\
\hline 2 & $\mathrm{~F}$ & 1 y $3 m$ & -0.85 & 0.55 & 6.47 & $\#$ & 5.8 & \# & 8.8/1086 & $\#$ & $\begin{array}{c}\text { APH/EN/ } \\
\text { ONH }\end{array}$ \\
\hline 3 & $M$ & $3 y 5 m$ & -5.8 & 1.00 & 2.69 & $<0.1 / 0.1$ & 7.74 & 0.01 & $\#$ & $\#$ & $\begin{array}{c}\text { APH/CCM/ } \\
\text { Coloboma }\end{array}$ \\
\hline 4 & $M$ & $3 y 5 m$ & -3.48 & 0.7 & 1.9 & $<1.0 / 0.6$ & 3.9 & 0.7 & $\#$ & 0.5 & APH \\
\hline 5 & $\mathrm{~F}$ & 13y 10m & -5.7 & 0.535 & 6.5 & $0.32 / 0.1$ & 1.89 & $\#$ & $\#$ & 0.54 & Normal \\
\hline 6 & $M$ & 14y 3m & -2.6 & 1.3 & 2.6 & 4.13 & 10.98 & 0.34 & $\#$ & 6.5 & Normal \\
\hline 7 & $M$ & $18 \mathrm{y} 5 \mathrm{~m}$ & -6.4 & 1.13 & 2.88 & 6.7 & 18.6 & 9.74 & $\#$ & 0.33 & Normal \\
\hline 8 & $M$ & $14 y 3 m$ & -3.0 & 1.65 & 3.74 & 18.1 & 14.5 & 0.96 & $\#$ & 0.73 & Normal \\
\hline 9 & $\mathrm{~F}$ & $16 y 9 m$ & -6.0 & 0.71 & 3.02 & \# & 2.57 & \# & $\#$ & \# & $\mathrm{APH}$ \\
\hline 10 & $\mathrm{~F}$ & $9 y 3 m$ & -4.49 & 0.63 & 0.005 & 22 & $<1$ & $\#$ & $\#$ & $<0.25$ & APH/EN \\
\hline 11 & $M$ & $14 y$ & -2.9 & 0.71 & 1.33 & 8.77 & 15.5 & 0.84 & $\#$ & 5.6 & APH \\
\hline
\end{tabular}

\#: unavailable data; M: male; F: female; APH: anterior pituitary hypoplasia; EN: ectopic neuro-hypophysis; ONH: optic nerve hypoplasia; CCM: corpus callosum malformations.

Reference values: LH: M: 0.8-7.6 mUi/mL; F: 1.1-11 mUi/mL, FSH: M: 0.7-11.1 mUi/mL; F: 2.8-11.3 mUi/mL, Cortisol: 5-25 ug/dL, Free testosterone (ftesto): 8.8-27 pg/mL, IGF1: 20-200, IGFBP3:

$1400-4250 \mathrm{ng} / \mathrm{mL}$, GH peak after ITT (insulin tolerance test) $<7 \mathrm{ng}$. 


\section{Sequence analysis}

All the exons of the HESXI gene were amplified at the expected sizes. In the SOD patient group, sequence analysis revealed an allelic variant in patient 2 , consisting of a $1772 \mathrm{~A}>\mathrm{G}$ transition (Figure 1) that results in replacement of an asparagine with a serine at position 125 (N125S). In the GHD patient group no sequence alterations could be identified. In the CPHD patient group, no mutations were found in the HESXI gene. In patients 4 and 5 , a monoallelic variant $(27 \mathrm{~T}>\mathrm{C}$; A9A) was found in exon 1 of the PROPl gene (Figure 2) and patient 10 was homozygous for this variant. (Figure 3). A further biallelic variant (59 A > G; A20S) was found patients 4, 5 and 10 (Figure 4 ).

\section{DISCUSSION}

Monoallelic and biallelic mutations in the HESXI gene are associated with a large spectrum of clinical phenotypes. At present, eleven mutations of the gene have been described. The patients presented with midline defects, optic nerve hypoplasia, neuro-pituitary ectopia

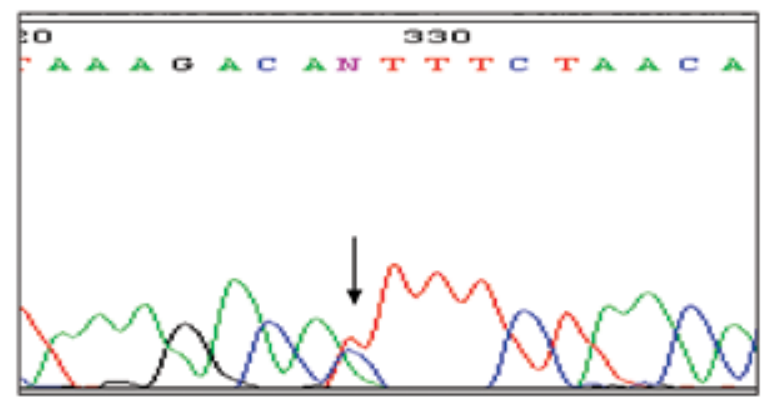

Figure 1. Segment of the chromatograms illustrating a HESX1 gene allelic variant in patient 2, consisting of a $1772 \mathrm{~A}>\mathrm{G}$ transition that results in the replacement of an asparagine by a serine at position 125 (N125S).

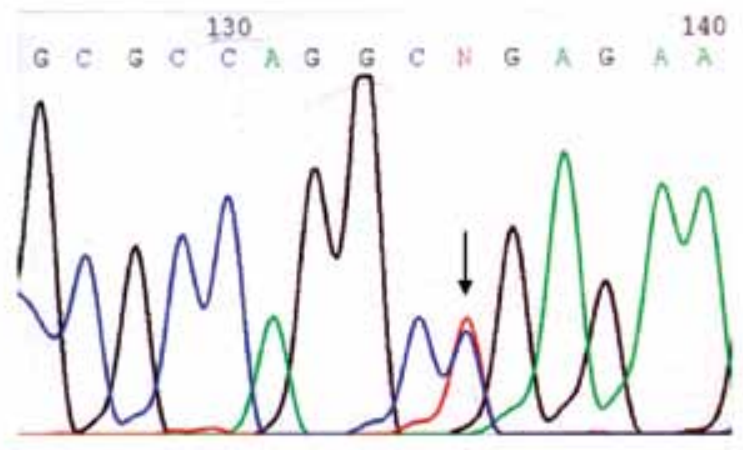

Figure 2. Segment of the chromatograms illustrating a PROP1 gene allelic variant in patients 4 and 5 , consisting of a monoallelic variant $(27 \mathrm{~T}>\mathrm{C}$, A9A). and pituitary hypoplasia associated with hormonal deficiencies (8). Individuals homozygous for the recessive mutation Rl60C presented with septo-optic dysplasia (SOD/Morsier's syndrome) with agenesis of the corpus callosum and CPHD (9). Nevertheless, individuals with monoallelic mutation presented with milder phenotypes suggesting that they result from haploinsufficiency of the HESXI protein (10).

The reported incidence of SOD is $1 / 10,000$ live births, and it is equally prevalent among males and females. Despite the generally sporadic nature of the condition, familial cases have been described. To date, Dattani and cols., have tracked more than 800 patients with SOD and pituitary hormone deficiency and identified mutations in less than $1 \%$ of individuals, confirming the rarity of mutations in HESXI (11).

The frequency of mutations in the HESXI gene is low, mutations in other genes are involved in the pathogenesis of SOD. For example, mutations in the

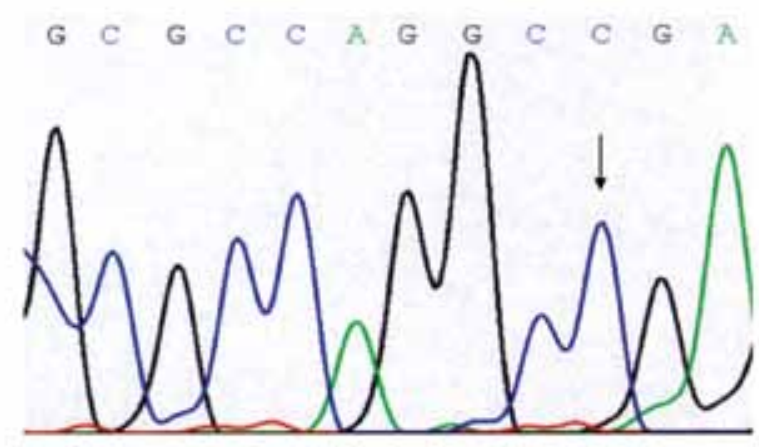

Figure 3. Segment of the chromatograms illustrating a $P R O P 1$ gene allelic variant in patient 10 , consisting of a monoallelic variant $(27 \mathrm{~T}>\mathrm{C}, \mathrm{A} 9 \mathrm{~A})$ in homozygose.
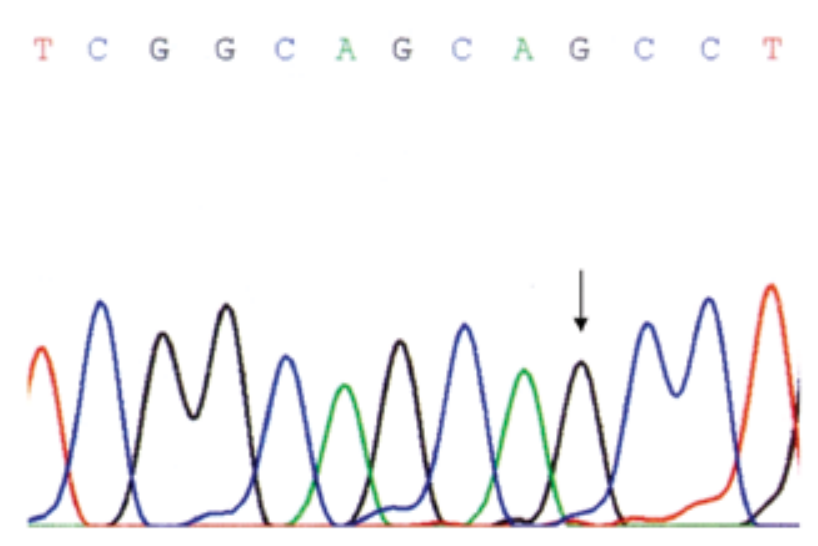

Figure 4. Segment of the chromatograms illustrating a $P R O P 1$ gene allelic variant in patients 4,5 and 10 , consisting of a biallelic variant $(59 \mathrm{~A}>\mathrm{G}$, A20S). 
SOX3 and SOX2 genes in combination with environmental factors such as very young maternal age, have been identified in individuals with SOD (8). Furthermore, mutations in other transcription factors such as PROPl; PITl, LHX3 and LHX4 can cause CPHD, whereas mutations in the growth hormone releasing receptor (GHRHR) gene are responsible for the majority of cases of GHD $(12,13)$.

To date, 22 mutations have been described in the PROPl gene in more than 170 patients suggesting that mutations in this gene may be the most common cause of CPHD accounting for approximately $50 \%$ of all familial cases. The incidence of PROPl mutations in sporadic cases is much lower $(14,15)$. In 2005, Turton and cols. (16), performed a mutational screen in a cohort of CPHD patients, consisting of 189 sporadic cases and 44 familial cases. The prevalence of mutations in the PROPI gene in sporadic cases was very low $(1.1 \%)$ compared to familial cases $(29.5 \%)$ (16). In the same year, Rainbow and cols. (17), studied the PROPI gene in 27 children with CPHD from 26 families (there were only 3 families with more than 1 member affected); they did not find any mutations in the PROPI gene, but a high incidence of a silent polymorphism $(27 \mathrm{~T}>$ C; A9A). The authors attributed these latter findings to the ethnic background of the studied patients and to the probable presence of a founder effect in certain regions with a high number of affected patients (17). However, it cannot be excluded that the observed polymorphism is in linkage disequilibrium with an undiscovered disease-causing mutation in a regulatory or intronic region.

In familial cases, all affected individuals are homozygous for inactivating mutations. The majority of the mutations described to date are located in the homeodomain of the DNA binding site, which forms a highly conserved region in mice and humans, with approximately $91 \%$ homology among the nucleotides. The loss of function in these mutations is due to a lack of DNAbinding and transactivation capacity. The most common mutation in the PROPI gene, corresponding to $50 \%$ $72 \%$ of all familial cases, is the deletion of 2 base pairs in exon 2, resulting in a frameshift mutation in codon 101 and introduction of a stop codon at position 109 (14).

As an exception to the usual location of PROPl mutations, Reynaud and cols. (18) described a mutation downstream from the homeodomain, leading to substitution of a tryptophan residue and introduction of a stop codon at position 194 in the transactivation do- main. This truncated protein retains only $34 \%$ of transcriptional activity when compared to the wild-type (18).

In 2000, Osório and cols. (19) described a novel $263 \mathrm{~T}>\mathrm{C}$ transition in exon 2 of the PROP-1 gene, resulting in the substitution of phenylalanine 88 by serine. F88, which corresponds to position 20 of the homeodomain in transcription factors of this class, constitutes the hydrophobic core of the first $\alpha$-helix forming the homeodomain. This finding underscores the critical role of this highly conserved hydrophobic phenylalanine in the structure and function of the homeodomain of PROP-1 (19).

In 2009, Dattani and cols. (20) ascertained three pedigrees with PROPI mutations from a large cohort of patients with variable degrees of CPHD and described four novel mutations in PROPI gene (20). The phenotypic variation observed in association with $P R O P I$ mutations both within and between families, together with the evolving nature of hormone deficiencies and sometimes changing pituitary morphology indicates a need for continual monitoring of these patients (20).

We did not find any mutation of the PROPI gene in the five CPHD patients studied. Our results are in accordance with literature, since the incidence of mutation in sporadic cases is very low. We confirmed three patients had allelic variant $\mathrm{A} 9 \mathrm{~A}$ and $\mathrm{N} 2 \mathrm{~S}$, which has already been described as polymorphism (21).

Among the patients with SOD, we found one individual with a monoallelic variant 59 A > G; N125S, a polymorphism previously described in the Afro-Caribbean population. Brickman and cols. (19), analyzing 461 patients, found 5 patients of Afro-Caribbean descent with variable severity of SOD with this allelic variant (9). Analyzing the DNA of 42 normal individuals of Afro-Caribbean background, they encountered 5 individuals homozygous for the wild-type allele, 17 individuals homozygous and 20 heterozygous for the $59 \mathrm{~A}>$ G; N125S allelic variant. Brickman and cols. (9) suggested that this variation may not be entirely silent, because the replacement of a serine with a proline at position 18 corresponds to the Propl homeodomain mutation implicated in the phenotype of the Ames dwarf mouse (9).

The absence of HESXI mutations in SOD patients is consistent with the findings of other mutational screens. The finding suggests that mutations in one or several other genes, possibly in conjunction with environmental factors or stochastic developmental defects, are involved in the pathogenesis of SOD phenotypes (21).

Disclosure: no potential conflict of interest relevant to this article was reported. 


\section{REFERENCES}

1. Carrière $C$, Gleiberman $A$, Lin $C$, Rosenfeld $M$. From panhypopituitarism to combined pituitary deficiencies: do we need the anterior pituitary? Rev Endocr Metab Disord. 2004;5(1):5-13.

2. Gleiberman AS, Fedtsova NG, Rosenfeld MG. Tissue interactions in the induction of pituitary: role of the ventral diencephalons, mesenchyme, and notocord. Dev Bio. 1999;213(2):340-53.

3. Aron DC, HowlettTA. Pituitary incidentalomas. Endocrinol Metab Clin North Am. 2000;29(1):205-21.

4. Carvalho LRS. Análise do gene HESX1 em pacientes portadores de deficiência do hormônio do crescimento associada ou não a defeitos de linha média. 2003. Tese [doutorado], Universidade de São Paulo, São Paulo.

5. Parks JS, Brown MR, Hurley DL, Phelps CJ, Wajnrajch MP. Heritable disorders of pituitary development. J Clin Endocrinol Metab. 1999;84:4362-70.

6. Machinis K, Pantel J, Netchine I, Leger J, Camand OJ, Sobrier ML, et al. Syndromic short stature in patients with germline mutation in the LIM homeobox LHX4. Am J Hum Genet. 2001;69(5):961-8.

7. Netchine I, Sobrier ML, Krude H, Schnabel D, Maghnie M, Mar$\cos \mathrm{E}$, et al. Mutations in LHX3 result in a new syndrome revealed by combined pituitary hormone deficiency. Nat Genet. 2000;25(2):182-6.

8. Mcnay DE, Turton JP, Kelberman D, Woods KS, Brauner R, Papadimitriou $A$, et al. HESX1 mutations are an uncommon cause of septooptic dysplasia and hypopituitarism. J Clin Endocrinol Metab. 2006;92(2):961-7.

9. Brickman JM, Clements M, Tyrell R, Mcnay D, Woods K, Warner $\mathrm{J}$, et al. Molecular effects of novel mutations in Hesx1/HESX1 associated with human pituitary disorders. Development. 2001;128 (24):5189-99.

10. Tajima T, Hattorri T, Nakajima T, Okuhara K, Sato K, Abe S, et al. Sporadic heterozygous frameshift mutation of HESX1 causing pituitary and optic nerve hypoplasia and combined pituitary hormone deficiency in a Japanese patient. J Clin Endocrinol Metab. 2003;88:45-50.

11. Kelberman D, Dattani MT. Genetics of septo-optic dysplasia. Pituitary. 2007; 10:393-407.
12. Reynaud R, Gueydan M, Saveanu A, Vallette-Kasic S, Enjalbert A, Brue $T$, et al. Genetic screening of combined pituitary hormone deficiency: experience in 195 patients. J Clin Endocrinol Metabol. 2006;91(9):3329-36

13. Dattani MT. Growth hormone deficiency and combined pituitary hormone deficiency: does the genotype matter? Clin Endocrinol. 2005;63:121-30.

14. Dattani MT, Kelberman D. Hypothalamic and pituitary development: novel insights into the aetiology. Eur J Endocrinol. 2007;157:3-14.

15. Vieira TC, Boldarine VT, Abucham J. Molecular analysis of PROP1, PIT1, HESX1, LHX3, and LHX4 shows high frequency of PROP1 mutations in patients with familial forms of combined pituitary hormone deficiency. Arq Bras Endocrinol Metabol. 2007;51(7):1097-103.

16. Turton JP, Mehta A, Raza J, Woods KS, Tiulpakov A, Cassas J, et al. Mutations within the transcription factor PROP1 are rare in a cohort of patients with sporadic combined pituitary hormone deficiency (CPHD). Clin Endocrinol. 2005;63 (1):10-8.

17. Rainbow LA, Reese SA, Shaikh MG, Shaw NJ, Colet T, Barrett TG, et al. Mutation analysis of POUF-1, PROP-1 and HESX-1 show low frequency of mutations in children with sporadic forms of combined pituitary hormone deficiency and septo-optic dysplasia. Clin Endocrinol. 2005;62:163-8.

18. Reynaud R, Barlier A, Vallette-Kasic S, Saveanu A, Guillet MP, Simoni $G$, et al. An uncommon phenotype with familial central hypogonadism caused by a novel PROP1 gene mutant truncated in the transactivation domain. J Clin Endocrinol Metabol. 2005;90:4880-7.

19. Osório MGF, Kopp P, Marui S, Latrônico AC, Mendonça BB, Arnhold IJP. Combined pituitary hormone deficiency caused by a novel mutation of a highly conserved residue (F88S) in the homeodomain of PROP-1. J Clin Endocrinol Metab. 2000;85:2779-85.

20. Kelberman D, Turton JP, Woods KS, Mehta A, Al-Khawari M, Greening J, et al. Molecular analysis of novel PROP1 mutations associated with combined pituitary hormone deficiency (CPHD). Clin Endocrinol. 2009;70(1):96-103.

21. NCB. Management Incorporated Services. Available from: http: // www.ncbi.com. Accessed on: 18 July 2008. 